\title{
Microbial regulation of global biogeochemical cycles
}

\author{
Johannes Rousk* and Per Bengtson \\ Department of Biology/Microbial Ecology, Lund University, Lund, Sweden \\ ${ }^{*}$ Correspondence: johannes.rousk@biol.lu.se \\ Edited by: \\ Lisa Y. Stein, University of Alberta, Canada \\ Reviewed by: \\ Pierre Offre, University of Vienna, Austria
}

Keywords: microbial ecology, biogeochemistry, stoichiometry, climate change, soil microbiology, elemental fluxes, respiration, aquatic microbiology

Global biogeochemical cycles of carbon and other nutrients are increasingly affected by human activities (Griggs et al., 2013). So far, modeling has been central for our understanding of how this will affect ecosystem functioning and the biogeochemical cycling of elements (Treseder et al., 2012). These models adopt a reductive approach built on the flow of elements between pools that are difficult or even impossible to verify with empirical evidence. Furthermore, while some of these models include the response in physiology, ecology and biogeography of primary producers to environmental change, the microbial part of the ecosystem is generally poorly represented or lacking altogether (Stein and Nicol, 2011; Treseder et al., 2012).

The principal pool of carbon and other nutrients in soil is the organic matter (Schimel, 1995). The turnover time of this reservoir is governed by the rate at which microorganisms consume it. The rate of organic matter degradation in a soil is determined by both the indigenous microbial community and the environmental conditions (e.g., temperature, $\mathrm{pH}$, soil water capacity, etc.), which govern the biogeochemical activities of the microorganisms (Waksman and Gerretsen, 1931; Schmidt et al., 2011). The dependences of these biogeochemical activity rates on environmental conditions such as $\mathrm{pH}$, moisture and temperature have been frequently studied (Conant et al., 2011; Schmidt et al., 2011). However, while various microorganisms involved in carrying out biogeochemical processes have been identified, biogeochemical process rates are only rarely measured together with microbial growth, and one of the biggest challenges for advancing our understanding of biogeochemical processes is to systematically link biogeochemistry to the rate of specific metabolic processes (Rousk and Bååth, 2011; Stein and Nicol, 2011). We also need to identify the factors governing these activities and if it results in feedback mechanisms that alter the growth, activity and interaction between primary producers and microorganisms (Treseder et al., 2012). By determining how different groups of microorganisms respond to individual environmental conditions by allocating e.g. carbon to production of biomass, $\mathrm{CO}_{2}$ and other products, a mechanistic as well as quantitative understanding of formation and decomposition of organic matter, and the production and consumption of greenhouse gases, can be achieved.

In this Research Topic, supported by the Swedish research councils' program "Biodiversity and Ecosystem Services in a Changing Landscape" (BECC), we intend to promote an alternative framework to address how cycling of carbon and other nutrients will be altered in a changing environment from the first-principle mechanisms that drive them-namely the ecology, physiology and biogeography of microorganisms. In order to improve the predictive power of current models, the alternative framework supports the development of new models of biogeochemical cycles that factor in microbial physiology, ecology, and biogeochemistry. Our ambition has been richly rewarded by an extensive list of submissions. We are pleased to present contributions including primary research targeting the microbial control of biogeochemistry, comprehensive reviews of how microbial processes and communities relate to biogeochemical cycles, identification of critical challenges that remain, and new perspectives and ideas of how to optimize progress in our understanding of the microbial regulation of biogeochemistry.

Our Research Topic presents new findings about the importance of the microbial community composition, their metabolic state, and the activity of enzymes for the fate and degradation of specific substrates such as chitin (Beier and Bertilsson, 2013), the degradation of more complex compounds such as those constituting plant litter (Moorhead et al., 2013; Rinkes et al., 2013), and the metabolism and biogeochemical cycling of one-carbon compounds (Aronson et al., 2013; Basiliko et al., 2013; Kappler and Nouwens, 2013). The environmental control and land-use perturbation of microbial communities and methane production were assessed in a comprehensive review (Aronson et al., 2013) as well as a case study (Basiliko et al., 2013) and a metaanalysis (Holden and Treseder, 2013). Other contributions have focused on how environmental variables that are affected by climate change can modulate microbial activities by e.g. their influence on the production and activity of enzymes (Steinweg et al., 2013), while Bradford (2013) has provided a comprehensive review of how microbial processes respond to warmer temperatures. These reviews are accompanied by a new suggestion for how we can achieve better predictions for microbial responses (and feedbacks) to climate change (de Vries and Shade, 2013), while Moorhead et al. (2013) identify knowledge gaps and provide important insights about how data on microbial communities, environmental conditions, and enzyme activities can be used to better inform enzyme-based models.

Several submissions have highlighted the importance for plant-microbial feedbacks for the regulation of organic matter decomposition and formation (Moorhead et al., 2013; Thomson 
et al., 2013; Churchland and Grayston, under review), the production of biogenic volatile organic compounds (Rinnan et al., 2013), and the community composition of methanogens and sulfate reducing bacteria (Zeleke et al., 2013). A very active research area in soil microbial ecology is presently how small amounts of labile carbon sources can trigger, or "prime," the decomposition of soil organic matter. A route toward a more general understanding of the regulation of plant-soil interaction for biogeochemistry, that may well facilitate our understanding of "priming effects," could be the incorporation of stoichiometric concepts (Dijkstra et al., 2013; Mooshammer et al., 2014). Stoichiometric variations in the concentration of nutrients, combined with variations in carbon and nutrient demands of different decomposer groups, also seems to be reflected in the degradation rate of plant litter (Rinkes et al., 2013). A comprehensive review of biogenic fixation of nitrogen demonstrates the importance of interactions between different biogeochemical cycles for nitrogen fixation in ecosystems with nitrogen-limited plant productivity (Rousk et al., 2013). These contributions emphasize that stoichiometric variations in nutrient concentrations are of importance for both factors that could determine the propensity for organic matter to accumulate in an ecosystem, and thus for carbon to be sequestered.

Some contributions to this Research Topic have also highlighted methodological challenges that urgently need attention. For instance, the ability of contemporary isotopic tracer methods to estimate microbial contributions to biogeochemical processes could be systematically overestimated (Hobbie and Hobbie, 2013), suggesting that estimates of the turnover of low molecular weight organic compounds, and possibly also for estimations of nitrogen transformation rates, need to be revised. Additionally, there is a need to move from laboratory-based estimations of the microbial role in ecosystem level processes, often omitting crucial components such as the presence of plants, to field-based assessments in intact systems (Rinkes et al., 2013).

The contributions to our Research Topic have opened up new horizons and stimulated conceptual developments in our basic understanding of the regulating factors of global biogeochemical cycles. Within this forum, we have begun to bridge Microbial Ecology and Biogeochemistry, connecting microbial activities at the microcosm scale to carbon fluxes at the ecosystem-scale, and linking above- and belowground ecosystem functioning. We are hopeful that we have initiated conceptual developments that can reach far beyond this Research Topic. It is a mere first step, but we are confident it is directed toward a predictive understanding of the microbial regulation of global biogeochemical cycles.

\section{ACKNOWLEDGMENTS}

This Research Topic was supported by the action-group "MICROGLOBE" within the "Biodiversity and Ecosystem Services in a Changing Landscape" (BECC) environment funded by the Swedish Research Council. We are grateful to the Frontiers team support and editorial endorsement of our ambitions.

\section{REFERENCES}

Aronson, E. L., Allison, S. D., and Helliker, B. R. (2013). Environmental impacts on the diversity of methane-cycling microbes and their resultant function. Front. Microbiol. 4:225. doi: 10.3389/fmicb.2013.00225
Basiliko, N., Henry, K., Gupta, V., Moore, T. R., Driscoll, B. T., and Dunfield, P. F. (2013). Controls on bacterial and archaeal community structure and greenhouse gas production in natural, mined, and restored Canadian peatlands. Front. Microbiol. 4:215. doi: 10.3389/fmicb.2013.00215

Beier, S., and Bertilsson, S. (2013). Bacterial chitin degradationmechanisms and ecophysiological strategies. Front. Microbiol. 4:149. doi: 10.3389/fmicb.2013.00149

Bradford, M. A. (2013). Thermal adaptation of decomposer communities in warming soils. Front. Microbiol. 4:333. doi: 10.3389/fmicb.2013.00333

Conant, R. T., Ryan, M. G., Ågren, G. I., Birge, H. E., Davidson, E. A., Eliasson, P. E., et al. (2011). Temperature and soil organic matter decomposition rates - synthesis of current knowledge and a way forward. Global Change Biol. 17, 3392-3404. doi: 10.1111/j.1365-2486.2011.02496.x

de Vries, F. T., and Shade, A. (2013). Controls on soil microbial community stability under climate change. Front. Microbiol. 4:265. doi: 10.3389/fmicb.2013.00265

Dijkstra, F. A., Carrillo, Y., Pendall, E., and Morgan, J. A. (2013). Rhizosphere priming: a nutrient perspective. Front. Microbiol. 4:216. doi: 10.3389/fmicb.2013.00216

Griggs, D., Stafford-Smith, M., Gaffney, O., Rockström, J., Öhman, M. C., Shyamsundar, P., et al. (2013). Sustainable development goals for people and planet. Nature 495, 305-307. doi: 10.1038/495305a

Hobbie, J. E., and Hobbie, E. A. (2013). Microbes in nature are limited by carbon and energy: the starving-survival lifestyle in soil and consequences for estimating microbial rates. Front. Microbiol. 4:324. doi: 10.3389/fmicb.2013.00324

Holden, S. R., and Treseder, K. K. (2013). A meta-analysis of soil microbial biomass responses to forest disturbances. Front. Microbiol. 4:163. doi: $10.3389 /$ fmicb. 2013.00163

Kappler, U., and Nouwens, A. S. (2013). Metabolic adaptation and trophic strategies of soil bacteria-C1- metabolism and sulfur chemolithotrophy in Starkeya novella. Front. Microbiol. 4:304. doi: 10.3389/fmicb.2013.00304

Moorhead, D. L., Rinkes, Z. L., Sinsabaugh, R. L., and Weintraub, M. N. (2013). Dynamic relationships between microbial biomass, respiration, inorganic nutrients and enzyme activities: informing enzyme-based decomposition models. Front. Microbiol. 4:223. doi: 10.3389/fmicb.2013.00223

Mooshammer, M., Wanek, W., Zechmeister-Boltenstern, S., and Richter, A. A. (2014). Stoichiometric imbalances between terrestrial decomposer communities and their resources: mechanisms and implications of microbial adaptations to their resources. Front. Microbiol. 5:22. doi: 10.3389/fmicb.2014. 00022

Rinkes, Z. L., Sinsabaugh, R. L., Moorhead, D. L., Grandy, A. S., and Weintraub, M. N. (2013). Field and lab conditions alter microbial enzyme and biomass dynamics driving decomposition of the same leaf litter. Front. Microbiol. 4:260. doi: 10.3389/fmicb.2013.00260

Rinnan, R., Gierth, D., Bilde, M., Rosenørn, T., and Michelsen, A. (2013). Off-season biogenic volatile organic compound emissions from heath mesocosms: responses to vegetation cutting. Front. Microbiol. 4:224. doi: $10.3389 /$ fmicb.2013.00224

Rousk, J., and Bååth, E. (2011). Growth of saprotrophic fungi and bacteria in soil. FEMS Microbiol. Ecol. 78, 17-30. doi: 10.1111/j.1574-6941.2011.01106.x

Rousk, K., Jones, D. L., and DeLuca, T. H. (2013). Moss-cyanobacteria associations as biogenic sources of nitrogen in boreal forest ecosystems. Front. Microbiol. 4:150. doi: $10.3389 /$ fmicb. 2013.00150

Schimel, D. S. (1995). Terrestrial ecosystems and the carbon-cycle. Global Change Biol. 1, 77-91. doi: 10.1111/j.1365-2486.1995.tb00008.x

Schmidt, M. W. I., Torn, M. S., Abiven, S., Dittmar, T., Guggenberger, G., Janssens, I. A., et al. (2011). Persistence of soil organic matter as an ecosystem property. Nature 478, 49-56. doi: 10.1038/nature10386

Stein, L. Y., and Nicol, W. N. (2011). Grand challenges in terrestrial microbiology. Front. Microbiol. 2:6. doi: 10.3389/fmicb.2011.00006

Steinweg, J. M., Dukes, J. S., Paul, E. A., and Wallenstein, M. D. (2013). Microbial responses to multi-factor climate change: effects on soil enzymes. Front. Microbiol. 4:146. doi: 10.3389/fmicb.2013.00146

Thomson, B. C., Ostle, N. J., McNamara, N. P., Oakley, S., Whiteley, A. S., Bailey, M. J., et al. (2013). Plant soil interactions alter carbon cycling in an upland grassland soil. Front. Microbiol. 4:253. doi: 10.3389/fmicb.2013.00253

Treseder, K. K., Balser, T. C., Bradford, M. A., Brodie, E. L., Dubinsky, E. A., Eviner, V. T., et al. (2012). Integrating microbial ecology into ecosystem models: challenges and priorities. Biogeochemistry 109, 7-18. doi: 10.1007/s10533-0119636-5 
Waksman, S. A., and Gerretsen, F. C. (1931). Influence of temperature and moisture upon the nature and extent of decompositiion of plant residues by microorganisms. Ecology 12, 33-60

Zeleke, J., Sheng, Q., Wang, J.-G., Huang, M.-Y., Xia, F., Wu J-H., and Quan, Z. (2013). Effects of Spartina alterniflora invasion on the communities of methanogens and sulfate-reducing bacteria in estuarine marsh sediments. Front. Microbiol. 4:243. doi: 10.3389/fmicb.2013.00243

Received: 11 February 2014; accepted: 27 February 2014; published online: 14 March 2014.
Citation: Rousk J and Bengtson P (2014) Microbial regulation of global biogeochemical cycles. Front. Microbiol. 5:103. doi: 10.3389/fmicb.2014.00103

This article was submitted to Terrestrial Microbiology, a section of the journal Frontiers in Microbiology.

Copyright (c) 2014 Rousk and Bengtson. This is an open-access article distributed under the terms of the Creative Commons Attribution License (CC BY). The use, distribution or reproduction in other forums is permitted, provided the original author(s) or licensor are credited and that the original publication in this journal is cited, in accordance with accepted academic practice. No use, distribution or reproduction is permitted which does not comply with these terms. 